\title{
HUBUNGAN VARIABEL DEMOGRAFI DAN DIMENSI BUDAYA DENGAN PERILAKU KOMPLAIN WISATA WAN HOTEL BERBINTANG DI BALI
}

\author{
Nosahari Febrin Jokohael ${ }^{1}$ \\ Ni Wayan Sri Suprapti² \\ Ni Nyoman Kerti Yasa ${ }^{3}$
}

\author{
${ }^{1.2 .3}$ Fakultas Ekonomi Universitas Udayana (Unud), Bali, Indonesia \\ e-mail: nosahari@gmail.com
}

\begin{abstract}
ABSTRAK
Penelitian ini dilakukan untuk mengetahui hubungan variabel demografidan dimensi budaya dengan perilaku komplain wisatawan hotel berbintang di Bali.Responden dalam penelitian ini adalah 60 responden wisatawan asing dan 60 responden wisatawan domestik.Data dianalisis dengan menggunakan metode statistik seperti distribusi frekuensi, chi-square test dan crosstab analysis.Hasil penelitian menunjukkan jika dilihat dari variabel demografi, wisatawan asing yang berpendapatan tinggi cenderung melakukan komplain melalui pengambilan tindakan publik, sementara wisatawan domestik yang berpendapatan rendah dan menengah lebih cenderung melakukan komplain melalui pengambilan tindakan pribadi. Dilihat dari dimensi budaya,wisatawan dengan dimensi jarak kekuasaan dalam konteks rendah, dalam budaya individualisme dan penghindaran ketidakpastian dalam konteks rendah lebih memilih untuk melakukan komplain melalui tindakan publik, sementara wisatawan dengan dimensi jarak kekuasaan dalam konteks tinggi, dalam budaya kolektivisme dan penghindaran ketidakpastian dalam konteks tinggi cenderung memilih melakukan komplain melalui tindakan pribadi.
\end{abstract}

Kata kunci: Perilaku komplain, demografi konsumen, dimensi budaya.

\begin{abstract}
This research was conducted to determine the relationship of demographic variable and cultural with complaints behavior of star hotels guest in Bali. Respondents in this study are 60 foreign guests and 60 domestic guests. This research uses consumer demographic and hofstede's cultural dimensions to investigate the differences of foreigner and domestic complaining behavior. The analysis techniques used were various statistical methods such as frequency distribution, crosstab analysis and chi-square test. The result showed that from demographic variable, foreign guests with high income tend to make public complaint while domestic guests with low and medium income are likely to engage with private complaint. Meanwhile, from cultural dimension perspective, guests with low power distance, in an individualism culture and low uncertainty avoidance are tend to take public complaint while guests with high power distance, in a collectivism culture and high uncertainty avoidance are tend to take private action.
\end{abstract}

Keyword: Consumer complaint, consumer demography, culture dimension. 


\section{PENDAHULUAN}

Bali merupakan salah satu destinasi wisata dunia dan pariwisata menjadi sektor handalan bagi pertumbuhan perekonomian daerah. Berkembangnya industri pariwisata telah mendorong munculnya berbagai hotel, mulai hotel bintang lima sampai hotel non-bintang. Banyaknya hotel mengakibatkan terjadinya persaingan yang ketat dalam menarik wisatawan melalui pelayanan yang memuaskan.

Dalam perspektif pemasaran, pemberian pelayanan yang memuaskan merupakan kunci untuk mempertahankan dan meningkatkan loyalitas pelanggan. Loyalitas pelanggan akan menjadi salah satu jaminan bagi eksistensi sebuah perusahaan. Namun demikian, tidak dapat dipungkiri bahwa memuaskan setiap pelanggan bukanlah pekerjaan yang mudah, selalu saja ada sekelompok pelanggan yang tidak puas terhadap pelayanan yang diterimanya.Pelanggan yang tidak puas kemungkinan akan melakukan tindakan komplain atau diam saja tetapi tidak akan pernah kembali lagi.

Pelanggan yang tidak puas dapat menempuhtiga jalur yaitu; (1) komplain dengan melakukan tindakan publik yang ditujukan langsung kepada pihak perusahaan; (2) komplain dengan melakukan tindakan pribadi sepeti memperingatkan keluarga dan teman akan pengalaman buruknya; dan (3) memilih tidak melakukan tindakan apapun (Lovelock dan Writz, 2007). Hasil identifikasi terhadap sejumlah komplin yang disampaikan oleh para wisatawan melalui kotak komplin di dua hotel di Kawasan Kuta Bali menunjukkan bahwa beberapa alasan tamu melakukan komplain antara lain proses check-in yang berbelit-belit dan membutuhkan waktu lama, keterlambatan penjemputan di bandara, kamar tidak 
sesuai dengan gambar yang ditampilkan pada website hotel dan travel agent, ketersediaan fasilitas hotel yang kurang memadai dan dirasakan tidak sesuai dengan klasifikasi hotel berbintang, harga dan kualitas makanan yang tidak sesuai dengan ekspektasi tamu, serta kualitas sumber daya manusia yang kurang kompeten.

Hasil-hasil studi yang membahas tentang perilaku komplain menyatakan bahwa tindakan komplain yang dilakukan oleh pelanggan ditentukan oleh beberapa faktor seperti faktor demografi (jenis kelamin, usia, pendidikan, pendapatan, asal negara, dan sebagainya), faktor budaya (jarak kekuasaan, individualisme vs kolektivisme, maskulin vs feminin, atau penghindaran ketidakpastian) (Heung dan Lam, 2003; Yuliati dan Anzola, 2009; Ngai et al., 2007; Tronvol, 2007; Liu dan McClure, 2001; Liu et al., 2001, Seo, 2012). Hasilhasl studi tersebut menunjukkan bahwa perbedaan faktor demografi dan latar belakang budaya menentukan perilaku pelanggan pasca keputusan pembelian. Sebagian besar studi-studi tersebut dilakukan di Negara-negara Barat dan relatif sedikit dilakukan di Indonesia (Ngai et al., 2007; Ferguson dan Phau, 2012; Kim dan Lynn, 2007; Mueller et al., 2003).

Didasari oleh adanya ketidakpuasan wisatawan dan perilaku komplain di dua hotel tersebut serta terbatasnya studi-studi tentang perilaku komplin di Negara-negara Timur khususnya Indonesia, maka penelitian ini bertujuan menjelaskan hubungan demografi wisatawan (seperti jenis kelamin, usia, pendidikan, pendapatan, dan asal negara) dan dimensi budaya (jarak kekuasaan, 
individualisme vs kolektivisme, dan penghindaran ketidakpastian) dengan perilaku komplain wisatawan hotel berbintang.

Studi oleh Metehan dan Yasemin (2011) di Ankara Turki menjelaskan bahwa karakteristik demografi yang berbeda akan bervariasi dalam perilaku komplain. Variabel demografi seperti pendapatan, level pendidikan, jenis kelamin dan usia berpengaruh terhadap perilaku komplain. Mensah dan Nimako (2012) dalam studinya di Ghana menjelaskan bahwa faktor-faktor demografi seperti usia, jenis kelamin dan tingkat pendidikan memainkan peran yang sangat penting dalam perilaku komplain dan merupakan prediktor yang baik dari perilaku komplain konsumen tertentu.

Penelitian lainnya yang menunjukan hubungan variabel demografi dengan perilaku komplain konsumen menunjukkan bahwa, kecenderungan konsumen asal Indonesia yang melakukan komplain memiliki tingkat pendidikan dan pendapatan yang lebih tinggi (Phau dan Sari, 2004).Lovelock dan Wirtz (2007) menjelaskan bahwa, hasil penelitian secara konsisten menunjukkan orang-orang dalamdari kondisi sosial ekonomi yang lebih tinggi lebih mungkin untuk melakukan komplain daripada orang-orang dengan kondisi sosial ekonomi yang lebih rendah.Pendidikan yang lebih baik, pendapatan yang lebih tinggi, keterlibatan sosial yang tinggi memberi mereka kepercayaan diri, pengetahuan dan motivasi untuk menyampaikan masalah yang mereka temui.Motif konsumen dalam melakukan komplain adalah untuk mendapatkan penyelesaianataupun ganti rugi.

Salah satu faktor demografi yang mempengaruhi perilaku komplain konsumen adalah jenis kelamin.Pria dan wanita memiliki sifat dasar yang 
berbeda.Pria lebih menggunakan rasio atau logika sementara wanita lebih menggunakan emosi.Sifat dasar yang berbeda dari pria dan wanita membuat jenis kelamin sebagai faktor penting dalam membentuk karakteristik.. Mahayudin et al. (2010) mengemukakan bahwajenis kelamin memiliki hubungan yang erat dengan perilaku komplain konsumen, yaitu pelanggan pria cenderung melakukan komplain secara aktif dibandingan dengan pelanggan wanita yang pasif.Penelitian yang dilakukan Phau dan Baird (2008) menjelaskan bahwa, tidak ada perbedaan yang signifikan antara pengeluh pria dan wanita. Namun hasil penelitian ini bertentangan dengan penelitian sebelumnya yang dilakukan oleh Heung dan Lam (2003) yang menyatakan bahwa, 60 persen konsumen wanita lebih suka mengungkapkan komplainnya dibandingkan dengan konsumen pria. Penelitian lainnya mengemukakan bahwa konsumen pria lebih cenderug untuk melakukan komplain dibandingkan dengan konsumen wanita.Petzer dan Mostert (2012) menjelaskan bahwa, konsumen wanita memiliki respon yang positif untuk melakukan komplain bila dibandingkan dengan konsumen pria.

Faktor lainnya yang diungkapkan dalam demografi konsumen adalah usia. Metehan dan Yasemin (2011) mengungkapkan bahwa, pelanggan Turki yang lebih tua cenderung melakukan komplain. Heung dan Lam (2003) menunjukkan bahwa, hubungan positif dan signifikan umur mempengaruhi perilaku komplain konsumen, dijelaskan bahwa konsumen dengan usia muda dan menengah cenderung untuk mengeluh daripada kelompok usia yang lebih tua. Yoga dan Warmika (2013) juga mengungkapkan bahwa, pelanggan dengan usia kurang dari 25 tahun cenderung untuk menyampaikan komplainnya dibandingkan dengan usia 
lebih dari 25 tahun. Ngai et al. (2007) menyatakan bahwa, konsumen dengan usia antara 31 sampai dengan 50 tahun lebih cenderung melakukan komplain melalui tindakan publik. MenurutTaghizadeh dan Panahi (2013) mengemukakan hasil yang berbeda dimana usia tidak berpengaruh pada perilaku komplain, komplain melalui tindakan publik, tindakan pribadi, beralih ke perusahan lain, dan tidak melakukan tindakan apapun.

Pendidikan mempengaruhi seorang konsumen dalam mengelola suatu informasi dan pengambilan keputusan karena konsumen dengan tingkat pendidikan yang lebih tinggi cenderung lebih mengetahui kekuatan dan peluang pasar (Williams, 2002).Dalam Phau dan Sari (2004) menjelaskan bahwa, responden Indonesia yang melakukan komplain cenderung berpendidikan tinggi.Heung dan Lam (2003) menjelaskan bahwa, konsumen dengan tingkat pendidikan yang lebih tinggi mungkin lebih mengetahui hak-hak mereka sebagai seorang konsumen dan metode pemulihan komplain saat mereka tidak puas dengan suatu pembelian. Diungkapkan juga bahwa alasan yang ditemukan adalah konsumen dengan tingkat pendidikan yang lebih tinggi mungkin lebih mengetahui hak-hak mereka sebagai seorang konsumen dan metode pemulihan komplain saat mereka tidak puas dengan suatu pembelian.Yuliati dan Anzola (2009) dijelaskan bahwa, konsumen dengan tingkat pendidikan menengah ke atas, dengan proporsi terbesar berpendidikan S1 lebih banyak melakukan komplain.Nimako dan Mensah (2012) menunjukkan hasil penelitian yang bertentangan, bahwa pendidikan tidak signifikan mempengaruhi perilaku komplain secara umum dalam konteks pasar telekomunikasi celuler Ghana. 
Konsumen dengan pendapatan lebih tinggi memiliki sumber daya yang lebih besar sehingga memungkinkan untuk lebih mudah mengekspresikan ketidakpuasan (Tronvoll, 2007).Konsumen dengan pendapatan lebih rendah cenderung mengambil tindakan pribadi seperti berhenti membeli produk tertentu ataupun menyebarkan informasi negatif dalam mengekspresikan ketidakpuasannya dengan satu produk (Fox, 2008).Hal ini bertentangan dengan Nimako dan Mensah (2012) menjelaskan bahwa, pendapatan tidak signifikan mempengaruhi perilaku orang yang melakukan komplain dan yang tidak melakukan komplain.

Perbedaan asal negara wisatawan akan menyebabkan perbedaan perilaku komplain yang berbeda-beda. Ngai et al. (2007) menjelaskan bahwa asal wisatawan signifikan mempengaruhi perilaku komplain secara tertutup (private complaint), di mana wisatawan yang berasal dari Asia (China, India, Japan, Malaysia, Filipina, Singapore, Sri Lanka dan Taiwan) lebih cenderung melakukan komplain secara tertutup. Ferguson dan Phau (2012) menjelaskan bahwa mahasiswa Australia lebih cenderung melakukan komplain secara langsung bertatap muka dengan staf dan menyampaikan komplainnya kepada mahasiswa lainnya.Sementara itu mahasiswa Indonesia atau Malaysia lebih cenderung melakukan komplain melalui media online, mengambil tindakan hokum dan berpindah ke penyedia layanan lainnya dibandingkan dengan mahasiswa Australia. Mueller et al. (2003) menjelaskan bahwa wisatawan korea lebih cenderung melakukan komplain dengan menyebarkan informasi dari mulut ke mulut sementara wisatawan Amerika lebih memilih untuk meninjau kembali 
perusahaan di masa depan. Berdasarkan penjelasan diatas dapat dirumuskan hipotesis sebagai berikut:

\section{H1a : Jenis kelamin memiliki hubungan yang signifikan dengan perilaku komplain wisatawan \\ H1b : Usia memiliki hubungan yang signifikan dengan perilaku komplain wisatawan \\ H1c : Pendidikan memiliki hubungan yang signifikan dengan perilaku komplain wisatawan \\ H1d : Pendapatan memiliki hubungan yang signifikan dengan perilaku komplain wisatawan \\ H1e : Asal negara memiliki hubungan yang signifikan dengan perilaku komplain wisatawan}

Selain faktor demografi, faktor budaya juga sangat menentukan perilaku konsumen, termasuk perilaku komplin.Budaya konsumen dapat berdampak pada cara dimana konsumen melakukan komplain dan juga memiliki pengaruh pada bagaimana kegagalan layanan dan upaya pemulihan layanan. Latar belakang budaya dapat dilihat dari dimensi jarak kekuasaan, dimensi individualism versus kolektivisme, dimensi penghindaran ketidakpastian (Hofstede, 1980).

Ngai et al. (2007) menjelaskanbahwadengan jarak kekuasaan yang tinggi, tamu Asia cenderung tidak melakukan komplain kepada pihak manajemen hotel. Jika komplain mereka pada akhirnya tidak diselesaikan dan dikelola dengan baik maka tamu Asia cenderung untuk tidak meningkatkan komplain kepada manajemen hotel.Sangat mungkin bahwa mereka tidak mengambil tindakan apapun atau beralih pada tindakan pribadi.Tamu Asia yang merupakan perwakilan budaya kolektivisme lebih mungkin untuk menyalahkan staf hotel atas ketidakpuasan yang dialami dan cenderung merasa terganggu untuk menyuarakan komplain. Di sisi lain, tamu non-asia sebagai perwakilan dari budaya 
individualisme seperti Amerika merasa bahwa mengeluh merupakan tanggung jawab mereka dan mereka percaya bahwa dengan mengeluh akan membawa dampak baik pada peningkatan kualitas di masa depan. Liu dan McClure (2001) menjelaskan bahwa, konsumen dalam kelompok budaya dengan penghindaran ketidakpastian dalam konteks tinggi cenderung tidak akan melakukan komplain kepada penjual.Heung dan Lam (2003) mengungkapkan bahwa budaya merupakan salah satu faktor yang berpengaruh dalam perilaku komplain. Di satu sisi, kebiasaan perilaku komplain pelanggan sebagian besar menentukan motifnya untuk mengajukan komplain. Di sisi lain, faktor budaya dapat mempengaruhi motif komplain pelanggan.

Jarak kekuasaan dalam konteks tinggi memiliki harapan yang tinggi untuk layanan yang diberikan dan menyampaikan kepuasaan yang lebih ketika perusahaan meminta maaf atau ketika orang yang berwenang dalam perusahaan tersebut berinteraksi selama proses pemulihan (Yuksel et al., 2006). Ngai et al. (2007) menjelaskan bahwa, adanya pengaruh dimensi budaya jarak kekuasaan (power distance) dengan perilaku komplain konsumen, di mana dengan budaya jarak kekuasaan dalam konteks tinggi, tamu Asia lebih kecil kemungkinan untuk mengeluh kepada manajemen hotel. Jika pada akhirnya komplain mereka tidak diselesaikan dan dikelola dengan memuaskan.Tamu Asia cenderung tidak meningkatkan pengaduan kepada manajemen hotel dan sangat mungkin mereka tidak mengambil tindakan ataupun tindakan pribadi.

Dimensi budaya kedua yang dikemukakan adalah individualisme versus kolektivisme.Liu dan McClure (2001) menyatakan bahwa, konsumen dalam 
budaya individualisme cenderung menyuarakan komplainnya dibandingkan dengan budaya kolektivisme.Selain itu, konsumen dalam budaya kolektivisme lebih mungkin untuk mengungkapkan komplainnya melalui tanggapan pribadi. Konsumen dengan budaya individualisme yang lebih tinggi cenderung melakukan komplain saat menerima layanan yang buruk namun tidak akan memuji saat mereka menerima layanan yang baik (Liu et al., 2001). Chan dan Wan (2008) menjelaskan bahwa saat mengalami ketidakpuasan, konsumen cina lebih cenderung untuk beralih dan menyebarkan informasi negarif (negative word of mount) daripada konsumen Amerika.

Penghindaran ketidakpastian didefenisikan sebagai sejauh mana individu merasa terancam oleh situasi yang tidak pasti atau tidak diketahui (Hofstede, 1991). Ngai et al. (2007), tamu Asia dengan penghindaran ketidakpastian yang lebih tinggi cenderung takut kehilangan muka untuk melakukan komplain. Tamu Asia memiliki kecenderungan tinggi untuk menghindari ketidakpastian dan akan memilih untuk tidak melakukan komplain jika mereka tidak tahu bagaimana dan dimana untuk melakukan komplain, atau kepada siapa mereka dapat menyampaikan komplain. Namun sebagian besar tamu Non-Asia menjawab bahwa mereka akan berusaha sebaik mungkin untuk menemukan cara untuk menyampaikan komplain ketika tidak puas dengan layanan sebuah hotel, bahkan jika mereka tidak akrab dengan saluran pengaduan. Liu dan McClure (2001) menjelaskan bahwa, konsumen dalam kelompok budaya dengan penghindaran ketidakpastian dalam konteks tinggi cenderung tidak akan melakukan komplain 
kepada penjual. Berdasarkan penjelasan diatas dapat dirumuskan hipotesis sebagai berikut:

\section{H2a : Jarak kekuasaan (power distance)memiliki hubungan yang signifikan dengan perilaku komplain wisatawan \\ H2b : Individualisme versus kolektivisme (individualism vs collectivism)memiliki hubungan yang signifikan dengan perilaku komplain wisatawan \\ H2c : Penghindaran ketidakpastin (uncertainty avoidance) memiliki hubungan yang signifikan dengan perilaku komplain wisatawan}

\section{METODE PENELITIAN}

Sampel penelitian ini diambil dari populasi wisatawan asing dan domestik yang menginap dan merasa tidak puas pada dua hotel berbintang di Bali.Sugiyono (2014) menyatakan bahwa bila sampel dibagi dalam kategori (misalnya: priawanita, pegawai negeri-swasta dan lain-lain), maka ukuran sampel setiap kategori minimal 30. Ukuran sampel dalam penelitian ini berjumlah 60 orang, terdiri atas 60 orang wisatawan domestik dan 60 orang wisatawan asing. Wisatawan asing sebagian besar berasal dari Australia, USA, Belanda, Jerman, Italia, sedangkan wisatawan domestik berasal dari kota-kota besar di Indonesia seperti Jakarta, Surabaya, Bandung, Bogor, dan Jogja.

Dilihat dari variabel usia, sampel terdiri atas 62,5 persen perempuan dan 37,5 persen laki-laki. Berdasar usia, sampel terdiri atas 67,5 persen berusia $\geq 31$ tahun dan 32,5 persen berusia $\leq 30$ Tahun. Sementara itu, dari segi pendidikan, 90 persen berpendidikan akademi atau universitas dan 10 persen hanya berpendidikan SMA atau dibawahnya. Dilihat dari segi pendapatan 51,7 persen berpendapatan tinggi (yaitu > Rp. 10.000.000 atau > USD 800/ bulan), 32,5 persen berpendapatan menengah (Rp. 5.000.000-10.000.000 atau USD 400-800/ 
bulan), dan 15,8 persen berpendapatan rendah ( $<$ Rp. 5.000.000 atau < USD 400/ bulan).

Instrumen penelitian yang digunakan adalah kuesioner sebagai alat untuk mengumpulkan data disebarkan kepada 60 wisatawan asing dan 60 wisatawan domestik yang menginap dan merasa tidak puas pada dua hotel berbintang di kawasan Kuta. Tiap variabel atau indikator penelitian yang disusun dalam pernyataan diukur dengan menggunakan skala Likert. Dalam penelitian ini skala Likert yang digunakan adalah skala lima tingkatan. Masing-masing alternative jawaban akan diberikan skor mulai dari sangat setuju (SS) diberi skor 5 hingga sangat tidak setuju (STS) diberi skor 1. Sementara dengan skala Likert, variabel yang diukur dijabarkan menjadi indikator variabel. Kemudian indikator tersebut dijadikan sebagai titik tolak untuk menyusun item-item instrument yang dapat berupa pernyataan atau pertanyaan. Skala ini digunakan untuk mengukur sikap responden di mana pengelompokan responden dalam budaya jarak kekuasaan, individualisme versus kolektivisme dan penghindaran ketidakpastian dibedakan berdasarkan rendah dan tinggi. Setiap variabel digunakan tiga pernyataan dengan total skor terendah adalah 3, skor tertinggi adalah 15, dan nilai tengah (median) 9 . Jika responden dengan total skor $<9$ dikelompokkan dalam responden dengan dimensi budaya dalam konteks rendah dan jika responden dengan total skor $>9$ dikelompokkan dalam responden dengan dimensi budaya dalam konteks tinggi.

Data dianalisis menggunakan statistik deskriptif berupa tabel distribusi frekuensi dan tabel silang (cross-tab) serta statistik non-parametrik berupa uji Chi-square untuk menguji hipotesis penelitian. 


\section{HASIL PENELITIAN}

Berdasar dimensi budaya, sampel terdiri atas 65 persen dari dimensi jarak kekuasaan dalam konteks tinggi dan 35 persen dari jarak kekuasaan konteks rendah; 60 persen berasal dari budaya kolektivisme dan 40 persen berasal dari budaya individualism; 50,8 persen dari dimensi penghindaran ketidakpastian dalam konteks tinggi dan 49,2 persen dari dimensi penghindaran ketidakpastian dalam konteks rendah. Sementara itu, berdasar tindakan komplin yang dilakukan, sampel terdistribusi menjadi 50 persen melakukan komplain langsung (kepada manajemen atau duty manager atau melakukan komplin kepada publik), sebanyak 35 persen memilih melakukan komplain secara tidak langsung atau tindakan pribadi (seperti memperingatkan keluarga dan teman tentang pengalaman buruknya selama menginap di suatu hotel, dan sebanyak 15 persen memilih untuk tidak melakukan tindakan apapun.

\section{Hubungan Variabel Demografi dengan Perilaku Komplain}

Hasil uji Chi Square antara variabel demografi dengan perilaku komplain disajikan pada Tabel 1. Di antara lima variabel demografi, jenis kelamin, usia, dan pendidikan menunjukkan hubungan yang tidak signifikan dengan perilaku komplin, yang berarti hipotesis tidak terdukung. Dua variabel demografi yaitu pendapatan dan asal Negara menunjukkan hubungan yang signifikan dengan perilaku komplain atau hipotesis terdukung. 
Tabel 1.

Hasil Chi Square Test Demografi dengan Perilaku Komplain Wisatawan

\begin{tabular}{clccc}
\hline No. & Variabel Demografi & Nilai $\boldsymbol{X}^{\mathbf{2}}$ & Probabilitas & Keterangan \\
\hline 1 & Jenis Kelamin & 1,417 & 0,492 & Tidak Signifikan \\
2 & Usia & 4,687 & 0,096 & Tidak Signifikan \\
3 & Pendidikan & 1,437 & 0,487 & Tidak Signifikan \\
4 & Pendapatan & 42,598 & 0,000 & Signifikan \\
5 & Asal Negara & 42,590 & 0,000 & Signifikan \\
\hline
\end{tabular}

Sumber: Data diolah, 2015

Berdasar hasil uji hipotesis pada Tabel 1, selanjutnya dapat disajikan secara lebih rinci hubungan variabel pendapatan dan asal Negara dengan jenis komplin yang dipilih oleh wisatawan.Hasilnya disajikan pada Tabel 2.

Tabel 2.

Hasil Crosstab Analysis Variabel Demografidengan Perilaku Komplain

\begin{tabular}{clccc}
\hline & & \multicolumn{2}{c}{ Perilaku Komplain (\%) } \\
No. & \multicolumn{1}{c}{ Variabel Demografi } & Langsung & Tidak Langsung & $\begin{array}{c}\text { Tidak Melakukan } \\
\text { Tindakan Apapun }\end{array}$ \\
& & & \\
\hline $1 \quad$ & $\begin{array}{l}\text { Pendapatan } \\
\text { <5Juta / <USD 400 }\end{array}$ & 2,5 & 10,8 & 2,5 \\
& 5-10 Juta / USD 400-800 & 10,0 & 20,0 & 10,0 \\
& >10 Juta / > USD 800 & 37,5 & 4,2 & 15,0 \\
Asal negara & Domestik & 13,3 & 31,7 & 5,0 \\
& Asing & 36,7 & 3,3 & 10,0 \\
\hline
\end{tabular}

Sumber: Data diolah, 2015

Data pada Tabel 2 menunjukkan bahwa dilihat dari variabel pendapatan, proporsi tertinggi yang melakukan komplain langsung adalah responden dengan kategori pendapatan tinggi, disusul oleh wisatawan dengan kategori pendapatan menengah dan pendapatan rendah.Kondisi seperti ini tampak pula pada jenis komplain yang ketiga yaitu tidak melakukan tindakan apapun.Sementara itu, pada jenis komplain tidak langsung, proporsi tertinggi berasal dari wisatawan dengan 
kategori menengah, disusul oleh wisatawan dengan kategori pendapatan rendah dan kategori pendapatan tinggi.Dilihat dari variabel asal negara, proporsi tertinggi yang melakukan komplain langsung adalah responden asing, Kondisi ini tampak juga pada jenis komplain yang ketiga yaitu tidak melakukan tindakan apapun Kondisi yang berbeda terlihat pada jenis komplain kedua yaitu proporsi tertinggi yang melakukan komplain tidak langsung adalah responden domestik.

\section{Hubungan Dimensi Budaya dengan Perilaku Komplain}

Hasil Chi-Square Testuntuk mengetahui sifat atau hubungan dimensi budaya dengan perilaku komplain yang disajikan dalam Tabel 3.Berdasarkan Tabel 3 hasil uji dimensi budaya yakni jarak kekuasaan, individualisme vs kolektivisme, dan penghindaran ketidakpastian menunjukan hubungan yang signifikan dengan perilaku komplain atau hipotesis terdukung.

Tabel 3.

Hasil Chi Square TestDimensi Budaya dengan Perilaku Komplain Wisatawan

\begin{tabular}{clccc}
\hline No. & \multicolumn{1}{c}{ Variabel Budaya } & Nilai $X^{2}$ & Probabilitas & Keterangan \\
\hline 1 & Jarak Kekuasaan & 15,242 & 0,000 & Signifikan \\
& Individualisme versus & 34,851 & 0,000 & Signifikan \\
2 & Kolektivisme & 24,764 & 0,000 & Signifikan \\
\hline
\end{tabular}
Sumber: Data diolah, 2015

Berdasar hasil uji hipotesis pada Tabel 3, selanjutnya dapat disajikan secara lebih rinci hubungan variabel jarak kekuasaan, individualisme vs kolektivisme, dan penghindaran ketidakpastian dengan jenis komplain yang dipilih oleh wisatawan.Hasilnya disajikan pada Tabel 4.

Tabel 4. 
Hasil Crosstab Analysis Dimensi Budaya dengan Perilaku Komplain

\begin{tabular}{|c|c|c|c|c|}
\hline \multirow[b]{2}{*}{ No. } & \multirow[b]{2}{*}{ Dimensi Budaya } & \multicolumn{3}{|c|}{ Perilaku Komplain (\%) } \\
\hline & & Langsung & Tidak Langsung & $\begin{array}{l}\text { Tidak Melakukan } \\
\text { Tindakan Apapun }\end{array}$ \\
\hline \multirow[t]{3}{*}{1} & Jarak Kekuasaan & & & \\
\hline & Rendah & 24,2 & 4,2 & 6.7 \\
\hline & Tinggi & 25,8 & 30,8 & 8,3 \\
\hline \multirow[t]{3}{*}{2} & Individualisme vs Kolektivisme & & & \\
\hline & Rendah & 17,5 & 32,5 & 10,0 \\
\hline & Tinggi & 32,5 & 2,5 & 5,0 \\
\hline \multirow[t]{3}{*}{3} & Penghindaran Ketidakpastian & & & \\
\hline & Rendah & 35,8 & 8,3 & 5,0 \\
\hline & Tinggi & 14,2 & 26,7 & 10,0 \\
\hline
\end{tabular}

Sumber: Data diolah, 2015

Data Tabel 4 menunjukkan bahwa dilihat dari variabel jarak kekuasaan, proporsi tertinggi yang melakukan komplain langsung adalah responden dengan dimensi jarak kekuasaan konteks tinggi.Kondisi seperti ini tampak pula pada jenis komplain yang kedua yaitu tidak langsung dan ketiga yaitu tidak melakukan tindakan apapun.Dilihat dari variabel individualism versus kolektivisme, proporsi tertinggi yang melakukan komplain langsung adalah responden dengan dimensi budaya konteks tinggi (individualisme).Sementara itu, pada jenis komplain tidak langsung, proporsi tertinggi berasal dari responden dengan dimensi budaya konteks rendah (kolektivisme). Kondisi seperti ini tampak pula pada jenis komplain yang ketiga yaitu tidak melakukan tindakan apapun.

\section{PEMBAHASAN}

Tiga di antara lima variabel demografi wisatawan yaitu jenis kelamin, usia, dan pendidikan menunjukkan hubungan yang tidak signfikan dengan perilaku komplin. Itu berarti,baik wisatawan laki-laki maupun wisatawan perempuan memiliki perilaku yang tidak berbeda dalam hal melakukan komplin 
sebagai tindak lanjut ketidakpuasannya terhadap layanan hotel.Temuan ini didukung oleh penelitian sebelumnya yang dilakukan oleh Phau dan Baird (2008) yang menyimpulkan bahwa tidak ada perbedaan yang signifikan antara perilaku komplain laki-laki dan perempuan.Namun hasil ini bertentangan dengan penelitian yang dilakukan oleh Mahayudin et al. (2010) mengemukakan bahwa jenis kelamin memiliki hubungan yang erat dengan perilaku komplain konsumen, yaitu pelanggan pria cenderung melakukan komplain secara aktif dibandingan dengan konsumen wanita yang pasif.

Menurut variabel usia menunjukan bahwa tidak ada perbedaan yang signifikan dengan perilaku komplain. Perilaku komplain responden usia muda ataupun tua tidak berbeda. Hasil temuan ini didukung oleh penelitian sebelumnya yang dilakukan oleh Taghizadeh dan Panahi (2013) yang menyimpulkan bahwa tidak ada perbedaan yang signifikan usia dengan perilaku komplain seseorang. Hal sebaliknya dikemukakan oleh Heung dan Lam (2003) menunjukkan bahwa, hubungan positif dan signifikan umur mempengaruhi perilaku komplain konsumen, dijelaskan bahwa konsumen dengan usia muda dan menengah cenderung untuk mengeluh daripada kelompok usia yang lebih tua.

Menurut variabel pendidikanmenunjukan bahwa tidak ada perbedaan yang signifikan dengan perilaku komplain.Perilaku komplain responden dengan pendidikan rendah dan tinggi tidak berbeda.Hasil temuan ini didukung oleh penelitian sebelumnya yang dilakukan oleh Nimako dan Mensah (2012) yang menyimpulkan bahwa tingkat pendidikan tidak signifikan mempengaruhi perilaku komplain.Konsumen dengan tingkat pendidikan yang lebih tinggi mungkin lebih 
mengetahui hak-hak mereka sebagai seorang konsumen dan metode pemulihan komplain saat mereka tidak puas dengan suatu pembelian (Heung dan Lam, 2003).

Menurut variabel pendapatan menunjukan terdapat perbedaan yang signifikan dengan perilaku komplain.Perilaku komplain responden berpendapatan tinggi berbeda dengan perilaku komplain wisatawan berpendapatan rendah. Hasil temuan ini didukung oleh penelitian sebelumnya yang dilakukan Fox (2008) bahwa, konsumen dengan pendapatan yang lebih rendah cenderung mengambil tindakan pribadi seperti berhenti membeli produk tertentu ataupun menyebarkan informasi negative dalam mengekspresikan ketidakpuasannya dengan satu produk.Hal ini dikarenakan konsumen dengan pendapatan lebih tinggi memiliki sumber daya yang lebih besar sehingga memungkinkan untuk lebih mudah mengekspresikan ketidakpuasan (Tronvoll, 2007). Wisatawan dengan pendapatan tinggi merasa bahwa apa yang diayarnya untuk mendapatkan layanan hotel yang baik, ternyata tidak sesuai dengan ekspektasinya, sehingga menjadi lebih berani untuk menyampaikan kekecewaannya kepada pihak manajemen. Selain itu, dengan pendapatan yang tinggi, mereka merasa mampu untuk membayar layanan dengan standar kualitas layanan yang tinggi pula, sehingga bila terjadi perbedaan antara harapan dengan kenyataan yang diterimanya, mereka merasa sangat kecewa. Wisatawan dengan pendapatan menegah hingga rendah dengan sumber keuangan yang terbatas memiliki kepercayaan diri yang kurang lebih merasa khawatir jika pengaduannya akan diterima dengan baik oleh manajemen ataukah tidak akan diselesaikan dan dengan fakta bahwa wisatawan ini cenderung 
membeli produk dan layanan dengan harga murah (mendapatkan harga promo untuk menginap disuatu hotel). Hal inilah yang cenderung mendorong wisatawan tersebut untuk berkomunikasi satu dengan yang lain untuk menyampaikan dan menginformasikan ketidakpuasan yang dialaminya.

Menurut variabel asal negara menunjukan terdapat perbedaan yang signifikan dengan perilaku komplain.Perilaku komplain responden dalam kelompok wisatawan asing berbeda dengan perilaku komplain respondendalam kelompok wisatawan domestik. Hasil temuan ini didukung oleh penelitian sebelumnya yang dilakukan olehFerguson dan Phau (2012) yang menyimpulkan bahwa mahasiswa Indonesia lebih cenderung melakukan komplain melalui tindakan pribadi, sementara mahasiswa Australia lebih memilih untuk menyampaikan komplain langsung kepada penyedia layanan.Ngai et al. (2007) menjelaskan bahwa asal wisatawan signifikan mempengaruhi perilaku komplain secara tertutup (private complaint), di mana wisatawan yang berasal dari Asia (China, India, Japan, Malaysia, Filipina, Singapore, Sri Lanka dan Taiwan) lebih cenderung melakukan komplain secara tertutup.Asal negara memiliki keterikatan dengan budaya dimana jumlah perbedaan sikap komplain antara kelompok budaya merupakan salah satu sebab dari perbedaan asal negara seseorang.Indonesia dengan kecenderungan budaya kolektivisme yang tinggi mendorong mereka untuk menahan emosi negatif di lingkungan publik agar tidak merasa malu. Namun mereka akan cenderung menyampaikan komplainnya dalam kelompok mereka untuk melindungi orang lain dari kegagalan layanan yang sama. Sementara wisatawan asing dengan kecenderungan dalam budaya individualisme lebih 
mengedepankan kepentingan pribadi sehingga dapat bertindak lebih agresif dengan langsung menyampaikan komplain untuk mendapatkan hak mereka.

Menurut variabel jarak kekuasanmenunjukan terdapat perbedaan yang signifikan dengan perilaku komplain.Perilaku komplain responden dengan jarak kekuasaan dalam konteks tinggi berbeda dengan perilaku komplain responden dengan jarak kekuasaan konteks rendah. Hasil temuan ini didukung oleh penelitian sebelumnya yang dilakukan oleh Ngai et al. (2007) yang menyimpulkan bahwa konsumen dengan dimensi jarak kekuasaan tinggi cenderung memilih pengambilan tindakan pribadi seperti memperingatkan keluarga dan teman tentang pengalaman buruknya sementara konsumen dengan dimensi jarak kekuasaan rendah lebih memilih untuk menyampaikan komplainnya secara langsung kepada pihak manajemen hotel. Hofstede (2009) menjelaskan bahwa konsumen Cina (kolektivisme) dengan jarak kekuasaan dalam konteks tinggi lebih kecil kemungkinan untuk melakukan komplain ketika mengalami kegagalan layanan dan ketidakpuasan.Konsumen dari kelompok jarak kekuasaan yang tinggi cenderung memiliki harapan yang lebih tinggi dari penyedia layanan, lebih puas ketika penyedia layanan meminta maaf dan ketika orang-orang yang memiliki kekuasaan lebih terlibat langsung dalam pemulihan layanan (Lin et al. (2007). Wisatawan dari jarak kekuasaan rendah memiliki keyakinan bahwa setiap individu memiliki kekuasaan yang sama dan harus diperlakukan sama. Hal inilah yang mendorong seorang dari budaya jarak kekuasaan dalam konteks rendah lebih berani dalam menyuarakan komplain langsung.Sementara wisatawan dari dimensi jarak kekuasaan dalam konteks tinggi lebih merasa bahwa pihak hotel lebih 
memiliki kekuasaan yang besar dibandingkan dengan mereka, sehingga mereka lebih takut untuk menyampaikan komplainnya jika pada akhirnya komplain mereka tidak dapat terselesaikan dengan baik.

Menurut variabel individualisme vs kolektvismedengan menunjukan terdapat perbedaan yang signifikan dengan perilaku komplain.Liu dan McClure (2001) yang menyimpulkan bahwa konsumen dengan budaya individualisme cenderung menyuarakan komplainnya langsung sementara konsumen dengan budaya kolektivisme lebih mungkin mengungkapkan komplainnya melalui tindakan pribadi. Tamu dari budaya kolektivisme (Asia) lebih mungkin untuk menyalahkan staf hotel atas ketidakpuasan yang dialami dan cenderung merasa terganggu untuk menyuarakan komplain, sementara tamu dari budaya individualisme (Non-Asia) merasa bahwa itu merupakan tanggung jawab mereka untuk mengeluh dan mereka percaya bahwa dengan mengeluh akan membawa dampak baik pada peningkatan kualitas di masa depan (Ngai et al.,2007).Karakteristik dari dimensi budaya individualisme yang memiliki kepercayaan diri yang tinggi, keberanian dan lebih mengutamakan kepuasan diri sendiri menyebabakan wisatawan dari kelompok ini lebih berani dalam menyampaikan komplain.Sementara wisatawan dari kelompok budaya kolektivisme berusha untuk menekan emosi negatif agar selalu terjaga keharmonisan atau menjaga hubungan baik dengan pihak hotel sehingga mereka lebih cenderung akan memilih untuk berinteraksi dengan teman terdekat untuk membantu dalam pengambilan keputusan akan tindakan yang perlu dilakukan.Chan dan Wan (2008) menjelaskan bahwa saat mengalami 
ketidakpuasan, konsumen cina lebih cenderung untuk beralih dan menyebarkan informasi negarif (negative word of mount) daripada konsumen Amerika.

Variabel penghindaran ketidakpastianmenunjukan terdapat perbedaan yang signifikan dengan perilaku komplain.perilaku komplain responden dalam budaya penghindaran ketidakpastian dalam konteks rendah dengan perilaku komplain responden dalam budaya penghindaran ketidakpastian dalam konteks tinggi. Seo (2012) menjelaskan bahwa budaya Jepang juga menunjukkan tingginya tingkat penghindaran ketidakpastian yang berarti orang jepang tidak menyukai ketidakjelasan dan ketidakpastian.Hasil temuan ini didukung oleh penelitian sebelumnya yang dilakukan olehLiu dan McClure (2001) menjelaskan bahwa, konsumen dalam kelompok budaya dengan penghindaran ketidakpastian dalam konteks tinggi cenderung tidak akan melakukan komplain kepada penjual. Hal yang sama juga dikemukakan oleh Ngai et al. (2007) yang menyimpulkan bahwa konsumen Asia yang dikategorikan dalam budaya dengan dimensi penghindaran ketidakpastian dalam konteks tinggi lebih takut kehilangan muka untuk melakukan komplain, mereka akan lebih memilih untuk tidak melakukan komplain jika tidak mengetahui bagaimana, dimana untuk mengeluh ataupun kepada siapa mereka akan mengeluhnamun konsumen dengan dimensi penghindaran ketidakpastian dalam konteks rendah akan berusaha menemukan cara untuk menyampaikan komplainnya bahkan jika mereka tidak akrab dengan saluran pengaduan. Wisatawan dari kelompok budaya penghindaran ketidakpastian dalam konteks tinggi dapat disebabkan oleh kurangnya pengetahuan wisatawan tersebut akan saluran penyampaian komplain ataupun 
tidak tahu bagaimana cara menyampaikan komplainnya sehingga wisatawan ini akan lebih merasa takut dan tidak ingin mengambil resiko untuk berusaha menyampaikan komplainnya. Sementara wisatawan dari kelompok budaya penghidaran ketidakpastian dalam konteks rendah lebih berani dalam mengambil resiko untuk mengutarakan komplainnya.

Hasil studi ini menunjukkan bahwa bahwa variabel demografi dan latar belakang budaya memang memiliki hubungan dengan perilaku komplain wisatawan.Mengingat komplain merupakan wujud dari ketidakpuasan, maka untuk mencegah terjadinya komplain, langkah pertama yang strategis adalah memberikan layanan sesuai dengan harapan wisatawan.Langkah ini tentu saja berdampak pada upaya meningkatkan kompetensi sumber daya manusia. Langkah kedua, untuk mencegah perilaku komplain atau memberi penanganan bila komplain harus terjadi, maka pihak manajemen perlu memperhatikan latar belakang demografi dan budaya wisatawan untuk mengantisipasi jenis komplain yang akan ditempuh.

\section{SIMPULAN DAN SARAN}

Berdasarkan hasil analisis data dan pembahasan yang telah diuraikan, maka dapat disimpulkan bahwa dari lima demografi konsumen hanya tiga variabel yang memiliki hubungan signifikan dengan perilaku komplain yaitu pendapatan da nasal negara. Sementara menurut dimensi budaya, ketiga dimensi budaya yaitu jarak kekuasaan, individualism versus kolektivisme dan penghindaran ketidakpastian memiliki hubungan signifikan dengan perilaku komplain. 
Keterbatasan dalam penelitian ini adalah sampel penelitian ini hanya diambil pada dua hotel bintang empat dikawasan pantai kuta yang belum mewakili wisatawan yang menginap di hotel bintang empat di Bali secara keseluruhan sehingga diharapkan kedepannya peneliti lainnya dapat melakukan penelitian pada lebih dari dua hotel bintang empat dengan jumlah sampel yang lebih besar. Kedepannya bagi peneliti yang akan melakukan penelitian tentang perilaku komplain wisatawan domestik dan asing dapat melakukan cluster atau pengelompokankhususnya pada wisatawan asing berdasarkan benua seperti benua Asia, Australia, Eropa, dan Amerika serta pengelompokan wisatawan asing yang memiliki KITAS disebabkan oleh wisatawan tersebut tinggal dan menetap pada kawasan Indonesia dapat dikategorikan sebagai wisatawan domestik.

Hasil penelitian ini memiliki implikasi yang besar bagi hotel berbintang di kawasan pantai Kuta demi mempertahankan kualitas layanan dan lebih peka terhadap perilaku tamu selama menginap di hotel tersebut. Sebaiknya demi mengurangi dan mencegah terjadinya komplain dari wisatawan selama menginap, hotel perlu melakukan beberapa tindakan guna meningkatkan kualitas sumber daya manusia yakni staff hotel melalui program-program training yang dilaksanakan regular guna meningkatkan pengetahuan serta kualitas kerja karyawan agar layanan yang diberikan diharapkan akan sesuai dengan standarisasi hotel berbintang empat dan materi training yang disampaikan disesuaikan dengan kebutuhan masing-masing department di hotel itu sendiri. Perlunya perumusan kebijakan-kebijakan yang akan dipilih oleh manajemen hotel dalam pencegahan, penanganan dan dalam proses pemulihan layanan. Kebijakan dalam pencegahan 
komplain dapat berupa penyediaan saluran komplain baik berupa pendelegasian staff yang telah dipersiapkan untuk menangani komplain, serta nomor telefon ataupun email yang telah disediakan khusus untuk penyaluran komplain konsumen. Kebijakan lainnya yang dapat ditempuh yakni pemberian guest comment bagi konsumen untuk dilengkapi pada saat tamu masih menginap di hotel tersebut.Kebijakan penanganan komplain dapat berupa permintaan maaf yang akan disampaikan baik secara lisan maupun tertulisan yang disampaikan langsung oleh perwakilan manajemen hotel yakni setingkat manajer serta manajemen ikut berperan penting dalam penyediaan solusi bagi penyelesaian masalah yang dihadapi.Kebijakan dalam proses pemulihan dapat ditempuh dengan pemberian ganti rugi ataupun tambahan benefit bagi konsumen, dapat berupa pemberian upgrade kamar ke tipe kamar yang lebih tinggi, pemberian voucher makan malam ataupun spa dengan potongan harga tertentu, dan benefit lainnya yang akan disesuaikan dengan fasilitas dan layanan yang dimiliki hotel itu sendiri.

\section{REFERENSI}

Bijmolt, T.H.A.,Huizingh, E.K.R.E., dan Krawczyk, A. 2014. "Effects of complaint behaviour and service recovery satisfaction on consumer intentions to repurchase on the internet".Internet Research. Vol. 24, pp. $608-628$

Chan, Haksin dan Wan L.C. 2008. "Consumer responses to service failures: a resource preference model of cultural influences". Journal of International Marketing, Vol.16, pp. 72-97.

Dong, J dan Chen, T. 2006. “Consumer behavior study based on cultural values".Journal of Liaoning Institute of Technology, Vol.8, pp. 18-21.

Ferguson, Graham dan Phau, Ian.2012. "A cross-national investigation of university students' complaining behaviour and attitudes to 
complaining". Journal of International Education in Business, Vol. 5, pp.50 - 70 .

Heung, Vincent. C.S. \& Terry Lam. 2003. "Customer complaint behaviour towards hotel restaurant services", International Journal of Contemporary Hospitality Management, Vol. 15, pp. 283-289.

Hofstede, G. 1991. Culture and Organizations: software of the mind. New York: McGraw-Hill

Hofstede, G. 2009. Geert Hofstede cultural dimensions. Retrieved from http://www.geerthofstede.com/

Kim, J dan J Lynn. 2007. "Classification of Asian complainers in restaurant services. Asia Pacific", Journal of Tourism Research, 12(4), 365-375.

Liu, B.S.C., Furrer, O., dan Sudharshan D. 2001. "The Relationships Between Culture and Behavioural Intentions Toward Services", Journal of Service Research, Vol. 4 No.2, pp.118-129.

Liu, R.R dan P McClure. 2001. "Recognizing cross-cultural differences in consumer complaint behavior and intentions: an empirical examination". Journal of Consumer Marketing, Vol. 18 No. 1, pp. 5474.

Lovelock, Christopher dan Jochen Wirtz. 2007. Service Marketing People, Tedchnology, Strategy, $6^{\text {th }}$ Edition.

Mahayudin, N.H.M., Haron, S.A., dan Fah, B.C.Y. 2010. "Unpleasant Market Experience and Consumer Complain Behaviour", Asian Social Science, Vol 6 No.5, pp.63-69

Malhotra, N.K. 2009.Riset Pemasaran Pendekatan Terapan. Edisi Keempat Jilid 1. Jakarta : PT. Indeks Kelompok Gramedia

Mensah, Anthony Freeman dan Nimako, Simon Gyasi. 2012. "Influence of Demographic Variables on Complaining and Non-Complaining Motives and Responses in Ghana's Mobile Telephony Industry", European Journal of Business Management, Vol. 4 No. 12.

Metehan, Tolon dan Asude Zengin Yasemin. 2011. "Demographic Characteristics and Complaint Behaviour: An Empirical Study Concerning Turkish Customers". International Journal of Business and Social Sciene, Vol. 2 No.29.

Mowen, John C danMichael Minor. 2002. Perilaku Konsumen. Jilid Kedua. Jakarta: Erlangga. 
Mueller, RD. Palmer, A. Mack, R., dan McMullan, R. 2003."Service in The Restaurant Industry: An American and Irish Comparison of Service Failures and Recovery Strategies", International Journal Hospitality Management, Vol.22 pp. 359-418.

Ngai,E.W.T., Heung, V.C.S., Wong, Y.H dan Chan, F.K.Y. 2007. "Consumer complaint behaviour of Asians and non-Asians about hotel services: An empirical analysis", European Journal of Marketing, Vol. 41, pp.1375 1391.

Nimako, S.G dan Anthony Freeman Mensah. 2012. "Motivation for Customer Complaining and Non-Complaining Behaviour Towards Mobile Telecommunication Services", Asian Journal of Business Management, Vol.4 No.3, pp.310-320

Patterson, P. Cowley, K. dan Prasongsukarn, K. 2006."Service failure recovery: the moderating impact of individual-level cultural value orientation on perceptions of justice", International Journal of Research in Marketing, Vol. 23 No. 3, pp. 263-77.

Petzer, D.J dan P Mostert. 2012. "Attitude towards, and likelihood of, complaining in the banking, domestic airline and restaurant industries", Southern African Business Review, Vol.16, pp. 1-23

Phau, Ian dan Michael Baird. 2008. "Complainers versus non-complainers retaliatory responses towards service dissatisfactions", Marketing Intelligence \& Planning, Vol. 26, pp.587-604

Phau,Ian \& Riana Puspita Sari. 2004. "Engaging in complaint behaviour: An Indonesian perspective", Marketing Intelligence \& Planning, Vol. 22 , pp. $407-426$.

Singh, J. 1988. "Consumer complaint intentions and behavior: definitional and taxonomical issues". Journal of Marketing, Vol. 52 No. 1, pp. 93-107.

Seo, Y. 2012. "Cultural impact on consumer satisfaction and service quality evaluation in hotels".Theses, University of Nevada, Las Vegas.

Sugiyono. 2014. Metode Penelitian Bisnis (Pendekatan Kuantitatif, Kualitatif, dan $R \& D)$. Bandung : Penerbit Alfabeta.

Velazquez, B.M., Blasco, M.F., Saura, I.G., dan Contri, G.B. 2010. "Causes for complaining behaviour intentions: the moderator effect of previous customer experience of the restaurant", Journal of Services Marketing, Vol.24, pp.532-545.

Taghizadeh, Houshang dan Karim Panahi. 2013. "A comparative study of complaint behavior of loyal customers versus first customers", 
European Online Journal of Natural and Social Sciences, Vol.1 No. 3, pp. 330-337.

Tronvoll, B. 2007. "Complainer characteristics when exit is closed", International Journal of Service Industry Management, Vol. 18, pp. 25 - 51

Wang, Sijun dan Susan Peters. 2010. "A glimpse into the consumer complaining behavior of immigrants", Journal of consumer behavior, Vol.23.

Wiliams, T.G. 2002. "Social Class Influences on Purchase Evaluation Criteria", Journal of Consumer Marketing, Vol. 19 No. 3, pp.249-276

Yoga, I Made Sedana dan Gede Ketut Warmika. 2013. "Hubungan karakteristik demografi dengan perilku keluhan konsumen", Fakultas Ekonomi Universitas Udayana.

Yuksel, A., Kilinc, U.K., dan Yuksel, F. 2006. "Cross-National Analysis of Hotel Customers' Attitudes Toward Complaining and Their Complaining Behaviours", Tourism Management 27, pp.11-24.

Yuliati, Lilik Noor dan Yuza Anzola. 2009. "Tingkat Kepuasan Konsumen terhadap Tanggapan Perusahaan Pasca Tindakan Komplain Melalui Media Cetak", Jurnal Ilmu Keluarga dan Konsumen, Vol. 2 No. 2, pp.186-192. 